Article

\title{
Leaf vs. Whole-Plant Biotic Attack: Does Vine Physiological Response Change?
}

\author{
Tadeja Savi $^{1,2, * \mathbb{C}}$, Jose Carlos Herrera ${ }^{2} \mathbb{D}$ and Astrid Forneck ${ }^{2}$ \\ 1 Department of Integrative Biology and Biodiversity Research, Institute of Botany, University of Natural \\ Resources and Life Sciences, Vienna (BOKU), Gregor-Mendel-Straße 33, 1180 Vienna, Austria \\ 2 Department of Crop Sciences, Institute of Viticulture and Pomology, University of Natural Resources \\ and Life Sciences, Vienna (BOKU), Konrad Lorenz Strasse 24, A-3430 Tulln, Austria; \\ jose.herrera@boku.ac.at (J.C.H.); astrid.forneck@boku.ac.at (A.F.) \\ * Correspondence: tadeja.savi@boku.ac.at; Tel.: +43-1-47654-83115
}

check for updates

Citation: Savi, T.; Herrera, J.C.;

Forneck, A. Leaf vs. Whole-Plant Biotic Attack: Does Vine Physiological Response Change? Water 2021, 13, 1429. https:// doi.org/10.3390/w13101429

Academic Editors: Guido D'Urso and Teresa Afonso do Paço

Received: 20 April 2021

Accepted: 17 May 2021

Published: 20 May 2021

Publisher's Note: MDPI stays neutral with regard to jurisdictional claims in published maps and institutional affiliations.

Copyright: (c) 2021 by the authors. Licensee MDPI, Basel, Switzerland. This article is an open access article distributed under the terms and conditions of the Creative Commons Attribution (CC BY) license (https:// creativecommons.org/licenses/by/ $4.0 /)$.

\begin{abstract}
Phylloxera is one of the most invasive and widespread insects in viticulture. An increase in populations feeding on leaves and/or roots of formerly resistant grapevines has been observed, but information on leaf and whole plant phylloxera infestation effects is lacking. We monitored the water and carbon metabolism of vines (one rootstock $x$ scion combination) inoculated with insects' eggs on leaves (L) or both leaves and roots ( $+\mathrm{L}$ ). Nonstructural carbohydrates (NSC) in infested and noninfested tissue of different organs and plant biomass were measured at the end of the experiment. At the peak of the biotic stress treatment, the plants reduced transpiration by about $30 \%$ compared to control, while photosynthesis remained unaffected. Lower soluble NSC were measured in infested than in the nearby noninfested tissue of both $L$ and $R+L$ groups, suggesting sugar consumption by the insect, while infested roots increased starch content by fivefold. NSC were depleted in noninfested roots of $\mathrm{R}+\mathrm{L}$ plants as well, giving strength to the hypothesis of intense metabolites translocation in favor of the insect. A more distinct physiological depression in $\mathrm{R}+\mathrm{L}$ vines compared to $\mathrm{L}$ was highlighted, even if the total biomass reduction was more marked in $\mathrm{L}$ plants. Our preliminary results suggest that the insect reprograms plant metabolism stimulating a more conservative water use, while competing with the host plant for carbon resources. Further studies should validate current results and quantify the NSC invested in the plant's defense against the pest.
\end{abstract}

Keywords: phylloxera; gas exchange; NSC; grapevine; source-sink relationship; Kober 5BB

\section{Introduction}

Worldwide viticulture is threatened by new massive outbreaks of grape phylloxera (Daktulosphaire vitifoliae Fitch), an aphid-like sucking insect native to North East America that is nowadays spread all over the globe [1]. In fact, grape phylloxera is monophagous on Vitis species [1]. However, different phylloxera biotypes feed on young organs inducing host tissue proliferation and the formation of pocket-like galls on leaves or/and hook-shaped galls on root tips (nodosities) and tuberosities (galls on lignified roots). As a consequence of insect population development, yield loss, health decline or even death of susceptible Vitis species have been documented [1,2]. The resistance against the invasive insect is cultivar- and rootstock-specific, as well as root and/or leaf specific. However, it is also affected by the parentage (of resistant and susceptible species) of the often complex hybrids employed as rootstocks or grapevine cultivars. Furthermore, environmental conditions (diverse biotic-abiotic stress factors) and phylloxera strain play important roles in the plant-insect dyad [1,3-5]. The roots of American Vitis species (e.g., V. riparia, V. berlandieri, etc.) are mainly resistant to phylloxera, while the leaves are susceptible. In contrast, the European grapevine (Vitis vinifera) shows the opposite susceptibility/resistance phenotype [6]. Grafted plants with American parentage have been efficiently used for decades in buffering 
the damage caused by root feeding [7]. However, recent observations report breakdowns of rootstock resistance in commercial vineyards, as well as substantial damage of leaf-feeding phylloxera on formerly resistant scions $[4,8-10]$. The effects of root-feeding phylloxera on plant metabolism have been largely addressed [5,11-13]. On the other hand, the reasons behind the increasing infestation rates on leaves of interspecific hybrids ( $V$. vinifera $\times$ American Vitis species) and $V$. vinifera cultivars, as well as their effects on plant physiology are largely unknown [10]. Although $V$. vinifera increased susceptibility against leaf-feeding phylloxera has been largely documented in recent years worldwide, interspecific hybrids generally sustain a higher rate of leaf-feeding populations of D. vitifoliae [2]. However, even if at first sight it probably appears controversial and counterproductive, the planting of hybrids appears fundamental for a sustainable reduction of pesticides use in viticulture, since these scions often have a prominent fungus-resistance [14-16]. Cadle-Davidson [14] and Cadle-Davidson et al. [15] performed on more than 800 vines' accessions systematic screening of the effects of natural infection and artificial inoculation of downy and powdery mildew pathogens. These are considered two of the most common and deleterious fungal diseases in viticulture. The most resistant genotypes of American species and hybrids showing no disease symptoms were selected. On the other hand, fully resistant individuals could not be identified in $V$. vinifera, since these were generally rated as moderately resistant or susceptible to the fungus $[14,15]$. Unfortunately, the American genetic background makes hybrids less resistant against leaf phylloxera attack. So far, the effects of leaf infestation on plant physiology have been rarely analyzed, but the herbivory is likely to cause additional long-term economic losses to grape growers via plants' metabolic alterations $[17,18]$. In particular, a recent study using a complex vine hybrid (Frontenac, with minimum $V$. vinifera parentage) found that leaf phylloxera induces stomata formation in proximity to the insect habit, as well as boosts gene expression related to water, nutrient, and mineral transport which may promote a favorable environment for galling [18]. According to Forneck et al. [10] the worst real-case scenario forecasted to increase in the near future, is represented by infestation at both root and leaf level and its consequences have not been addressed yet. Hence, studying phylloxera-host plant interactions at different infestation levels (aboveground and whole plant) to predict the pest's impact on grapevine metabolism, long-term costs and wine quality is particularly urgent [8].

Understanding the nature of phylloxera damage on the physiology of different plant organs is thus an important step toward ameliorating the current and future vineyard management worldwide. We designed an experiment to investigate the effects of (i) leafinfestation and (ii) both root and leaf infestation on the water relations, carbon metabolism, and growth of a fungus resistant grape variety grafted on an interspecific breed rootstock [7]. We hypothesized a more marked physiological depression and growth in vines experiencing whole plant infestation, compared to those facing pest proliferation restricted to aboveground organs only.

\section{Materials and Methods}

\subsection{Experimental Design and Plant Material}

The experiments were carried out at the Institute of Viticulture and Pomology located in Tulln (Lower Austria). In total, 60 vines of Muscaris grafted on Kober 5BB were provided by a local nursery (Reben Iby KEG) and planted in $3 \mathrm{~L}$ pots in early spring. The above discussed current situation of phylloxera feeding on leaves of hybrids grafted on rootstocks is fully reflected in the choice of test plants. In fact, the scion Muscaris is an interspecific hybrid (Solaris $x$ Gelber Muskateller) with resistance against fungi used for quality wine production in Austria and elsewhere. Available information on its resistance/vulnerability to phylloxera is scarce, but leaf-feeding phylloxera has been documented on this cultivar [8]. Kober 5BB is a breed between American native species $V$. berlandieri and V. riparia. It has gained worldwide importance thanks to phylloxera-tolerance and its adaptability to a wide range of soil types [4,7]. Note that, in general, tolerance does not mean resistance. The insect indeed is able to live on the roots of several grafted grapevines and induces the 
formation of nodosities. The difference is that plant decline/death does not happen as in the susceptible genotypes such as $V$. vinifera. We chose to employ only one scion and one rootstock, since no screening was intended, but the main goal of the experiment was to understand the fundamental physiological changes in the interaction between plant and insect.

The used substrate was a mixture of potting soil and perlite (9:1). The plants were disposed equally spaced in the greenhouse and maintained well-watered for about one month to encourage vegetative growth. The crowns were thus standardized to one single shoot (about $45 \mathrm{~cm}$ long at that time) and washed with tap water to remove residuals of treatments. The pots were fertilized (10 g per pot, ENTEC vino, EuroChem Agro $\mathrm{GmbH}$ ) and moved into a quarantine cage made of wooden beams and polypropylene mesh $(125 \mu \mathrm{m})$. Two USB data logger sensors (UT330B, Uni-trend Technology, Hong Kong) recording air temperature $\left(T_{\text {air }}\right)$ and relative humidity $(\mathrm{RH})$ were installed in the quarantine cage $(1.2 \mathrm{~m}$ height) spaced about $5 \mathrm{~m}$. The recording was set at $1 \mathrm{~h}$ interval and the maximum daily water pressure deficit (between 12:00 and 15:00 h) was calculated as follows: saturation vapor pressure at $\mathrm{T}_{\mathrm{air}} \times(1-\mathrm{RH})$. PPFD was periodically measured in the central hours of the day with a quantum sensor (Quantum PAR meter, Hydrofarm Inc, CA, USA) at the top of plants $(130 \mathrm{~cm})$. At the end of the experiments, substrate samples of about $8 \mathrm{~g}$ each were collected from the central part of at least 3 pots per experimental category. The fresh mass (FM) and dry mass (DM, after $48 \mathrm{~h}$ at $\left.70^{\circ} \mathrm{C}\right)$ were measured with a precision balance, the substrate water content calculated as (FM-DM)/DM and expressed in $\mathrm{g} \mathrm{g}^{-1}$ (for additional details see Savi et al. [19]).

One week after crown standardization, the plants were randomly assigned to one of three experimental categories, i.e., leaf infested (L), root and leaf infested $(R+L)$ and noninfested control plants (C). The leaves and roots were inoculated with 100 phylloxera eggs collected from two different single founder lineages developing on Maréchal Foch (Biotype G) and Teleki 5C (Biotype C) potted plants, respectively [2]. The eggs were placed on moistened filter paper which was wrapped around one young leaf using aluminum foil or placed in an Eppendorf tube which was inserted upside-down in the substrate. All the pots $(\mathrm{C}, \mathrm{L}$, and $\mathrm{R}+\mathrm{L}$ ) were connected to automatic drip irrigation and enclosed in bags made of polypropylene tissue to prevent insects' migration and cross infestation. Furthermore, $C$ plants were separated from phylloxerated plants by a curtain made of the same mesh tissue. The plants were maintained for eight weeks in well-watered conditions by providing about $50 \mathrm{~mL}$ of water per pot and per day. The inoculation success was monitored twice per week by visual assessment of leaves. Root infestation was evaluated at the end of the experiment, when plants were uprooted. At the end of the experiment, all the plants showed good leaf phylloxera proliferation (about half of the leaves infested). On the other hand, the root insect population was less abundant, and the inoculation was not successful in about half of the plants, i.e., we could not find any nodosity on the roots, or only small signs of former infestation (without living insects or eggs).

\subsection{Physiological Measurements}

The pest effects on vines' physiology were investigated for eight weeks after inoculation through measurements of leaf conductance to water vapor $\left(\mathrm{g}_{\mathrm{s}}\right)$, transpiration $\left(\mathrm{E}_{\mathrm{L}}\right)$ and photosynthetic rates $(\mathrm{A})$, substomatal $\mathrm{CO}_{2}(\mathrm{Ci})$ and leaf temperature $\left(\mathrm{T}_{\text {leaf }}\right)$. Measurements were performed on the 28th, 34th, 44th, 51st and 56th day after inoculation between 11:00 and 14:00 $\mathrm{h}$ using a portable gas-exchange system (LCpro-SD, ADC BioScientific Ltd., Hertfordshire, UK) with light source set at $1000 \mu \mathrm{mol} \mathrm{m}{ }^{-2} \mathrm{~s}^{-1}$ and ambient $\mathrm{CO}_{2}$ (about $500 \mathrm{ppm}$ ). On each day, 5-8 plants per experimental category were randomly selected and measurements performed on the abaxial surface of one to three mature, undamaged leaves (usually 7th-11th from the base) per vine. For $\mathrm{L}$ and $\mathrm{R}+\mathrm{L}$ groups the measurements were performed on an ungalled leaf area adjacent to the galls. During measurements, the $\mathrm{T}_{\text {air }}$ and PPFD ranged about $28-35^{\circ} \mathrm{C}$ and $200-600 \mu \mathrm{mol} \mathrm{m}{ }^{-2} \mathrm{~s}^{-1}$, respectively. At the end of the experiment (56 days after inoculation), the leaf water status and functionality of PSII 
were also assessed ( $n=5-8$ ). Specifically, Fv/Fm measurements (Handy Pea, Hansatech, Norfolk, UK) were performed on a dark-adapted area of the same leaf blade used for gas-exchange measurements. The first nearby leaf was then detached, wrapped in cling film and its water potential $\left(\Psi_{\text {leaf }}\right)$ measured with a pressure chamber (3000 Series Plant Water Status Consoles, Soilmoisture, CA, USA).

\subsection{Sampling and Biomass Measurements}

At the end of physiological measurements performed 56 days after inoculation (end of the experiment), tissues for nonstructural carbohydrate (NSC) analyses were sampled from 5-8 plants per experimental category. Only experimental vines with a minimum of 50\% infested leaves and/or 30 root nodosities were chosen for sampling. From the aboveground plant organ, we sampled the young plant apex (about $5 \mathrm{~cm}$ long shoot tip), a section of the leaf blade used for physiological measurements (noninfested in case of $L$ and $R+L$ group), and the leaf galls (group L and $\mathrm{R}+\mathrm{L}$ ). In the latter case, about 30 galls were quickly excised from one to five infested leaves using a scalpel and opened to remove the insects and eggs with a brush. All the samples were inserted in Eppendorf tubes, snap frozen in liquid nitrogen and stored at $-80^{\circ} \mathrm{C}$ until processing (see Section 2.4). After sampling, the vines were gently uprooted and the soil debris removed. From the belowground plant organ, we sampled about $2 \mathrm{~g}$ (fresh weight) of noninfested young root tips, infested roots tips (with visible insect-induced nodosities) and older lignified roots. Root samples were about $1.5 \mathrm{~cm}$ long and $2-3 \mathrm{~mm}$ thick. The material was gently cleaned with distilled water, quickly dried with tissue, frozen and stored as described above.

After sampling, the absolute shoot length was measured with a meter tape. Then, the whole root system of the plants was gently drained under tap water to remove soil particles. The shoot and root biomass were then dried in an oven $\left(70{ }^{\circ} \mathrm{C}\right.$ for $\left.96 \mathrm{~h}\right)$ and the total dry mass measured.

\subsection{Nonstructural Carbohydrates (NSC) Analyses}

In order to study the phylloxera effect on carbohydrates content and partitioning, soluble NSC (glucose, fructose, sucrose) and starch were measured at the end of the treatment in different plant tissues (leaf apex, noninfested leaf, leaf galls, infested and noninfested root tips, see Section 2.3). After being ground to fine powder in liquid nitrogen and freeze-dried for $48 \mathrm{~h}$, about $15 \mathrm{mg}$ of sample were suspended in $1.5 \mathrm{~mL}$ of $80 \%$ ethanol. The soluble sugars were extracted through three cycles of heating $\left(\right.$ at $\left.90^{\circ} \mathrm{C}\right)$, centrifugation and supernatant collection $[20,21]$. The starch contained in the remaining pellet was digested with $\alpha$-amylase (70 $\mathrm{u}, 1 \mathrm{~mL}$ per sample) followed by amyloglucosidase ( $6 \mathrm{u}$ dissolved in $0.5 \mathrm{~mL}$, per $0.1 \mathrm{~mL}$ of subsample) solutions. In total, $0.6 \mathrm{~mL}$ of chloroform were added to each sample to precipitate the enzymes [21]; all the supernatants were then filtered through a syringe nylon filter with pore size of $0.45 \mu \mathrm{m}$ and, after appropriate dilution, analyzed with ion exchange chromatography (Dionex, ICS-5000, Thermo Fischer Scientific, MA, USA). Glucose, fructose, sucrose, and starch content (digested to glucose hydrolysate) were quantified using their reference standards with the software Chromeleon (v 7.2, Thermo Scientific, MA, USA). For additional details see Savi et al. [5].

\subsection{Statistics}

Statistical analyses were performed with R (v 3.5.1) and SigmaPlot (v 13, Systat Software Inc, CA, USA) software. The effect of different treatments was tested separately for each parameter. Normality of residuals and homogeneity of variances assumptions were verified. One-way ANOVA analysis was used, setting the selected parameter as the response variable and treatment as the explanatory variable. For significant tests $(p$ $\leq 0.05$ ), multiple comparison procedures (Holm-Sidak test) were carried out to detect statistically significant differences among groups. Student's t-test was used to compare two groups of data (for example leaf galls tissue of $\mathrm{L}$ and $\mathrm{R}+\mathrm{L}$ group). All values are given as mean \pm standard error of the mean (SEM). 


\section{Results}

Average minimum and maximum air temperatures recorded in the quarantine cage during the experimental time interval were 9 and $35^{\circ} \mathrm{C}$, respectively. The maximum water pressure deficit ranged between 0.3 and $7.0 \mathrm{kPa}$, with average values approaching $3.6 \mathrm{kPa}$ (see Figure S1 available as Supplementary Materials). The substrate water content measured at the end of the experiment was about $2 \mathrm{~g} \mathrm{~g}^{-1}$. A total of 56 days after inoculation, all plants were accurately checked and no phylloxera infestation was detected on leaves of $C$ and roots of L plants.

The transpiration rate $\left(\mathrm{E}_{\mathrm{L}}\right)$ and net photosynthesis $(\mathrm{A})$ significantly increased from the first day of measurements (about $1.2 \mathrm{mmol} \mathrm{m}^{-2} \mathrm{~s}^{-1}$ and $7.4 \mu \mathrm{mol} \mathrm{m}{ }^{-2} \mathrm{~s}^{-1}$, respectively) to the last (about $5.4 \mathrm{mmol} \mathrm{m}^{-2} \mathrm{~s}^{-1}$ and $10.9 \mu \mathrm{mol} \mathrm{m}^{-2} \mathrm{~s}^{-1}$, Figure 1).

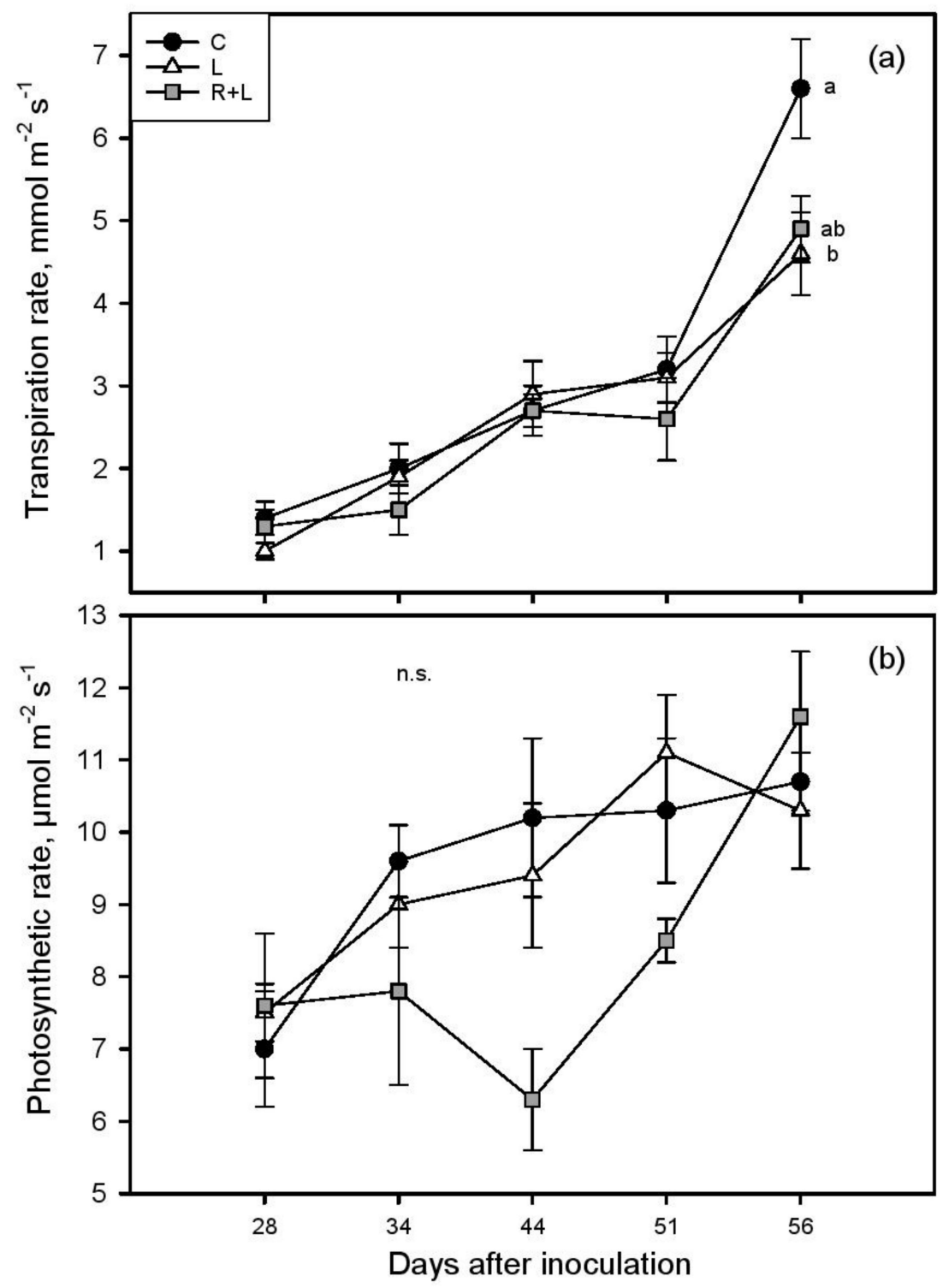

Figure 1. Transpiration $\left(\mathrm{E}_{\mathrm{L}}\right)(\mathbf{a})$ and photosynthetic $(\mathrm{A})(\mathbf{b})$ rates as measured in control (C, closed circles), leaf infested ( $\mathrm{L}$, open triangles), and both root and leaf infested ( $\mathrm{R}+\mathrm{L}$, grey squares) plants during the treatment application $(n=5-8)$. Different letters denote significant differences among groups; n.s. indicates lack of statistically significant differences.

During the monitoring period, leaf temperatures and stomatal conductance ranged between 28 and $37{ }^{\circ} \mathrm{C}\left(\mathrm{T}_{\text {leaf }}\right)$ and 0.04 and $0.43 \mathrm{~mol} \mathrm{~m}^{-2} \mathrm{~s}^{-1}\left(\mathrm{~g}_{\mathrm{s}}\right.$, Figure S2a,b). Both L 
and $\mathrm{R}+\mathrm{L}$ treatments significantly impacted vines' physiology and metabolism, but to a different extent. A total of 56 days after inoculation, lower $\mathrm{E}_{\mathrm{L}}$ was recorded in phylloxerated plants with respect to control, while A and photosynthetic efficiency (Fv/Fm: C, L, and $\mathrm{R}+\mathrm{L} 0.81 \pm 0.01,0.82 \pm 0.05$, and $0.82 \pm 0.01$, respectively) were equal. $\Psi_{\text {leaf }}$ averaged $-0.83 \mathrm{MPa}$ with higher (statistically significant) values recorded in $\mathrm{L}(-0.75 \pm 0.05 \mathrm{MPa})$ compared to $\mathrm{C}(-0.93 \pm 0.05 \mathrm{MPa})$ vines. During early stage of infection, the physiological parameters $\left(\mathrm{g}_{\mathrm{s}}, \mathrm{E}_{\mathrm{L}}, \mathrm{A}, \mathrm{Ci}, \mathrm{T}_{\text {leaf }}\right.$ ) tested separately for each measurement day, were not statistically different among three experimental groups. However, when all the data collected during the five measurements campaigns were pooled together, lower $\mathrm{E}_{\mathrm{L}}$ (by about $16 \%$ ) and lower $g_{s}$ (by about 26\%) were observed in plants attacked by the insect compared to $\mathrm{C}$ plants. Moreover, a closer focus to the peak of the experimental treatment (56 days after inoculation) revealed a marked and significant drop in $\mathrm{E}_{\mathrm{L}}$ in the $\mathrm{L}$ group compared to control plants, giving strength to previously described trends. We did not find a significant difference among experimental groups in absolute shoot length, but phylloxera generally led to smaller total plant biomass, which was particularly noticeable and statistically significant in leaf infested plants ( $-13 \%$ in relation to control, Figure 2$)$.

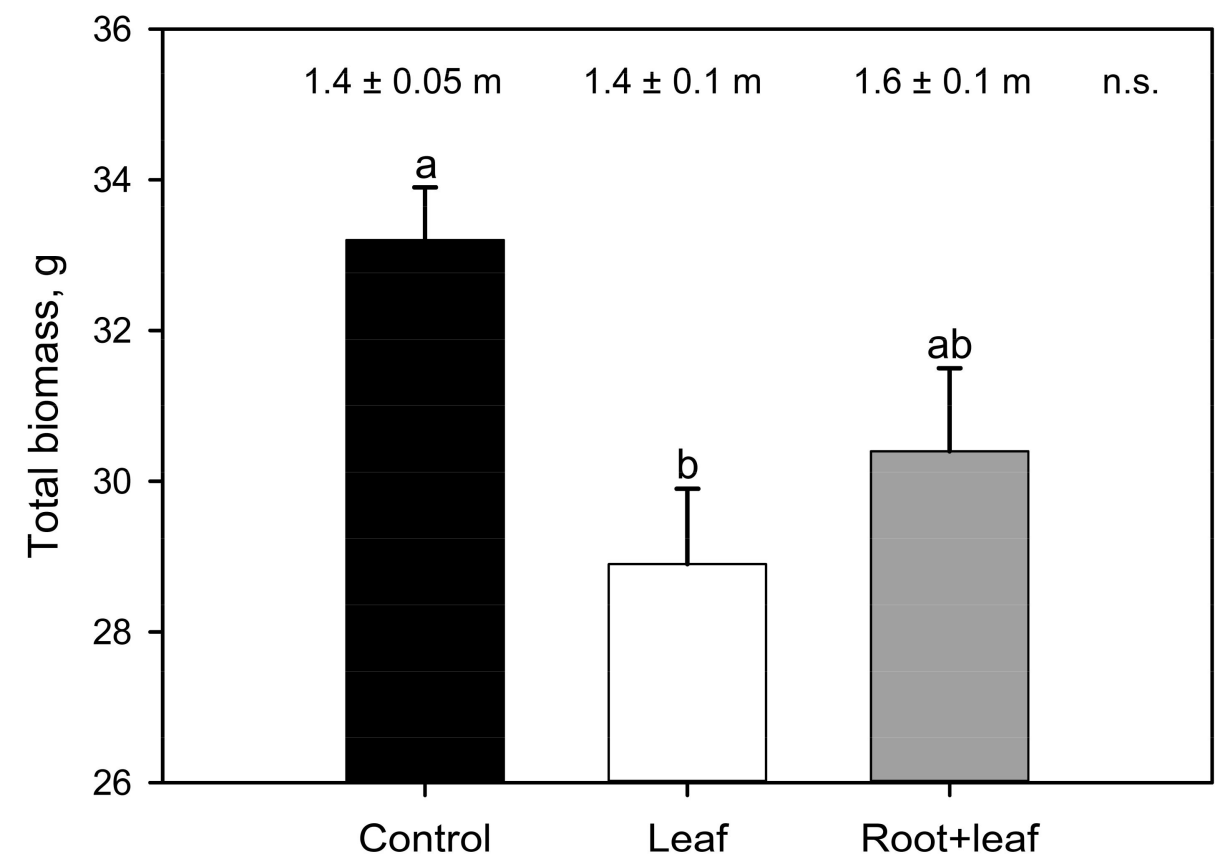

Figure 2. Total plant biomass (histogram) and absolute shoot length (top part) as measured in control (C, black bar), leaf infested ( $\mathrm{L}$, white bar), and both root and leaf infested ( $+\mathrm{L}$, grey bar) plants 56 days after inoculation. Different letters indicate significant differences among groups (one-way ANOVA); n.s. indicates lack of significant differences.

The NSC measured in aboveground and belowground organs of the experimental vines is summarized in Tables 1 and 2, respectively, and graphically presented in Figures 3 and 4 . The young apex had higher glucose and lower starch content than noninfested mature leaves, with similar values recorded in the three treatments (Table 1). The soluble NSC were significantly depleted in galled tissue compared to the nearby noninfested leaf blade in L (-41\%, Figure 3a) and even more in the $\mathrm{R}+\mathrm{L}(-48 \%$, Figure $3 \mathrm{~b})$ group. This result was mainly driven by sucrose content. Although lower starch content could be observed in galls compared to noninfested leaf (about $-1.2 \mathrm{mg} \mathrm{g}^{-1},-20 \%$ ), the biotic attack apparently did not induce striking alterations of this storage sugar in any of the aboveground organs. 

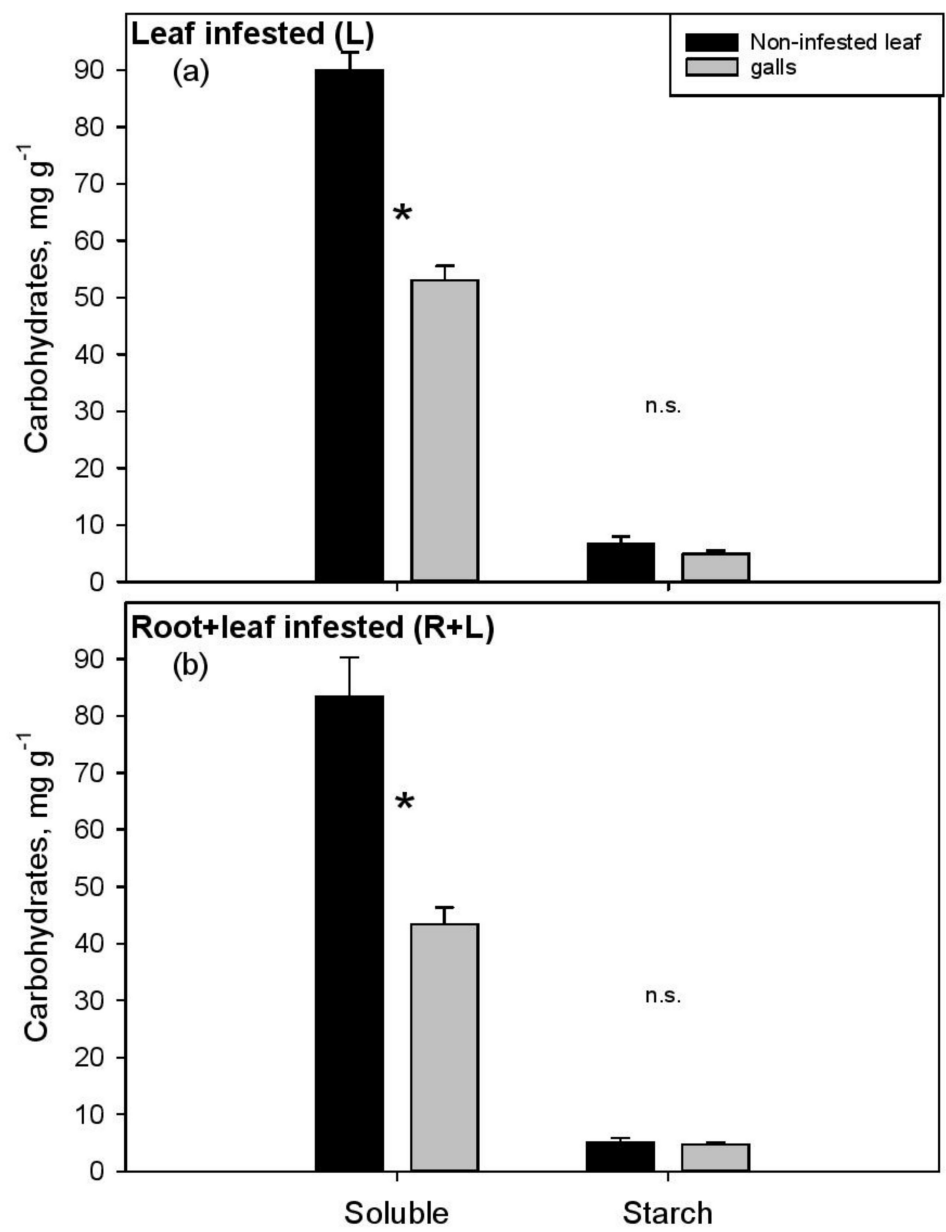

Figure 3. Soluble nonstructural carbohydrates and starch as measured in noninfested leaf portion (black bars) and in nearby galls (grey bars) sampled from leaf (L) (a) and both root and leaf infested $(\mathrm{R}+\mathrm{L})(\mathrm{b})$ plants 56 days after inoculation. * denotes significant difference between groups (Student's $t$-test); n.s. indicates lack of significant differences.

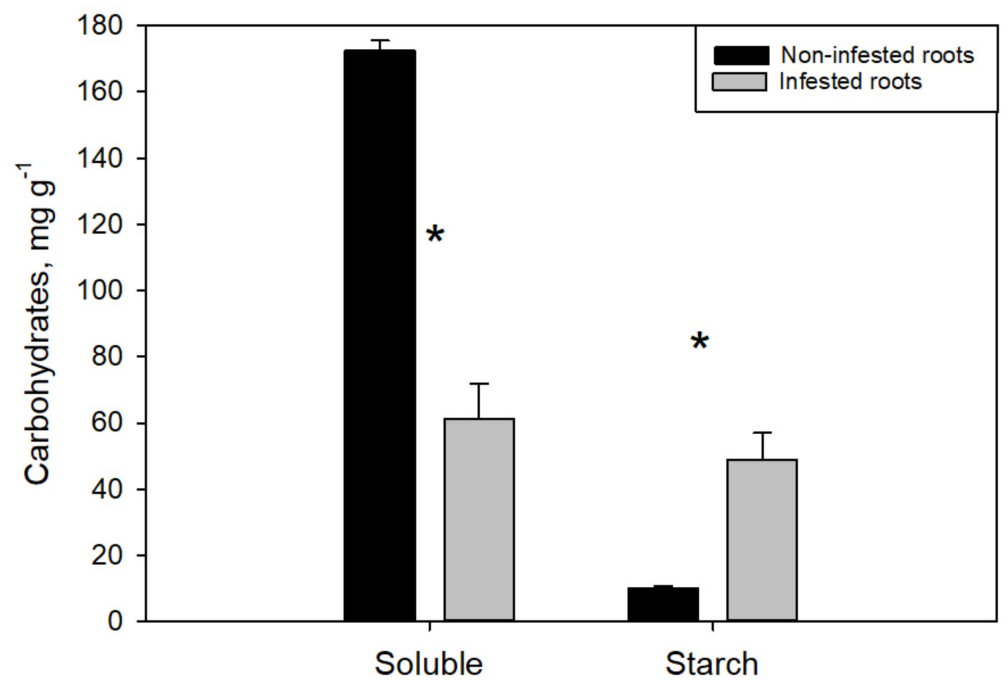

Figure 4. Soluble nonstructural carbohydrates and starch as measured in noninfested (black bars) and infested (grey bars) root tips sampled from both root and leaf infested plants $(R+L) 56$ days after inoculation. * indicates significant difference between groups (Student's t-test). 
Table 1. Glucose, fructose, sucrose and starch measured in aboveground organs sampled from control $(\mathrm{C})$, leaf $(\mathrm{L})$, and both root and leaf infested $(\mathrm{R}+\mathrm{L})$ plants 56 days after inoculation. * (and bold) indicates significant difference between $\mathrm{L}$ and $\mathrm{R}+\mathrm{L}$ group (Student's $t$-test).

\begin{tabular}{|c|c|c|c|c|}
\hline & Glucose, $\mathrm{mg} \mathrm{g}^{-1}$ & Fructose, $\mathrm{mg} \mathrm{g}^{-1}$ & Sucrose, $\mathrm{mg} \mathrm{g}^{-1}$ & Starch, $\mathrm{mg} \mathrm{g}^{-1}$ \\
\hline Category & \multicolumn{4}{|c|}{ Apex } \\
\hline C & $25.7 \pm 3.1$ & $6.8 \pm 1.0$ & $59.0 \pm 2.7$ & $2.6 \pm 0.3$ \\
\hline $\mathrm{L}$ & $20.7 \pm 2.5$ & $5.1 \pm 0.9$ & $57.4 \pm 4.2$ & $2.7 \pm 0.2$ \\
\hline \multirow[t]{2}{*}{$\mathrm{R}+\mathrm{L}$} & $26.2 \pm 3.9$ & $7.4 \pm 1.4$ & $49.8 \pm 6.4$ & $2.9 \pm 0.4$ \\
\hline & \multicolumn{4}{|c|}{ Noninfested leaf } \\
\hline $\mathrm{C}$ & $8.1 \pm 0.8$ & $4.0 \pm 0.5$ & $81.1 \pm 5.2$ & $6.2 \pm 0.5$ \\
\hline $\mathrm{L}$ & $6.5 \pm 0.9$ & $3.8 \pm 0.9$ & $79.7 \pm 3.5$ & $6.6 \pm 1.4$ \\
\hline \multirow[t]{2}{*}{$\mathrm{R}+\mathrm{L}$} & $5.5 \pm 0.6$ & $2.8 \pm 0.5$ & $75.1 \pm 5.9$ & $5.1 \pm 0.7$ \\
\hline & \multicolumn{4}{|c|}{ Leaf galls } \\
\hline $\mathrm{L}$ & $9.1 \pm 0.5$ & $4.1 \pm 0.3$ & $39.9 \pm 2.2$ * & $4.9 \pm 0.6$ \\
\hline $\mathrm{R}+\mathrm{L}$ & $8.7 \pm 0.6$ & $3.4 \pm 0.2$ & $31.2 \pm 2.3 *$ & $4.7 \pm 0.4$ \\
\hline
\end{tabular}

Table 2. Glucose, fructose, sucrose and starch measured in belowground organs sampled from control (C), leaf $(\mathrm{L})$, and both root and leaf infested $(\mathrm{R}+\mathrm{L})$ plants 56 days after inoculation. Different letters (and bold) denote significant differences within the groups root tips and old roots (one-way ANOVA).

\begin{tabular}{|c|c|c|c|c|}
\hline & Glucose, $\mathrm{mg} \mathrm{g}^{-1}$ & Fructose, $\mathrm{mg} \mathrm{g}^{-1}$ & Sucrose, $\mathrm{mg} \mathrm{g}^{-1}$ & Starch, $\mathrm{mg} \mathrm{g}^{-1}$ \\
\hline $\begin{array}{l}\text { Noninfested } \\
\text { roots }\end{array}$ & \multicolumn{4}{|c|}{ Root tips } \\
\hline $\mathrm{C}$ & $170.2 \pm 11.9$ a & $52.9 \pm 5.8 \mathrm{a}$ & $73.0 \pm 6.7 \mathrm{a}$ & $8.0 \pm 1.0 b$ \\
\hline $\mathrm{L}$ & $139.9 \pm 19.6$ a & $46.1 \pm 6.3 \mathrm{a}$ & $75.1 \pm 6.4 \mathrm{a}$ & $9.0 \pm 1.3 \mathrm{~b}$ \\
\hline $\begin{array}{c}\mathrm{R}+\mathrm{L} \\
\text { Infested } \\
\text { roots }\end{array}$ & $92.5 \pm 5.6 \mathrm{~b}$ & $28.3 \pm 1.2 b$ & $52.3 \pm 2.2 b$ & $10.1 \pm 0.7 b$ \\
\hline $\mathrm{R}+\mathrm{L}$ & \multicolumn{4}{|c|}{ Old roots } \\
\hline C & $3.2 \pm 2.1$ & $4.4 \pm 2.5$ & $23.7 \pm 5.0$ & $74.7 \pm 10.6 \mathrm{a}$ \\
\hline $\mathrm{L}$ & $3.1 \pm 1.8$ & $3.7 \pm 1.1$ & $27.4 \pm 4.0$ & $28.6 \pm 8.2 \mathrm{~b}$ \\
\hline $\mathrm{R}+\mathrm{L}$ & $1.6 \pm 0.4$ & $3.1 \pm 1.0$ & $24.9 \pm 1.3$ & $47.3 \pm 6.6 \mathrm{~b}$ \\
\hline
\end{tabular}

On the contrary, the starch concentration in infested root tips was fivefold higher that in noninfested root tips, while soluble NSC were, again, depleted by about $65 \%$ (Figure 4 ). Interestingly, the biotic attack had a negative effect on the noninfested roots as well, both in terms of soluble sugars and carbon reserves. In particular, plants under the phylloxera stress tended to progressively decrease glucose, fructose and sucrose concentration in the young noninfested root tips (Table 2), and this drop was far more drastic and statistically significant in $\mathrm{R}+\mathrm{L}$ compared to L plants ( $-40 \%$ vs. $-10 \%$, respectively). A similar carbon depletion was observed in old lignified roots in terms of starch reserves that dropped from $74.7 \pm 10.6 \mathrm{mg} \mathrm{g}^{-1}$ (C plants) to $28.6 \pm 8.2$ and $47.3 \pm 6.6 \mathrm{mg} \mathrm{g}^{-1}$, as measured in the $\mathrm{L}$ and $\mathrm{R}+\mathrm{L}$ group, respectively.

\section{Discussion}

This study compared, for the first time, the effects of leaf-feeding and both leaf and root feeding phylloxera on the water metabolism (intended as combination of leaf conductance to water vapor, transpiration and water potential values) and carbon assimilation of host vines. The proposed experimental design meets the actual situation in many European vineyards where root and leaf infestations occur and vines very often have to fight the pest on two fronts, i.e., aboveground and belowground. Results provide novel information on the compartmentalization of carbon reserves in different plant organs and in infested vs. noninfested tissues under the pressure of biotic attack. We want to immediately point out that the choice of test plants was not meant to generalize or extrapolate the information but shall present only an example that mimics a real case. 
The study vines belonging to both $\mathrm{L}$ and $\mathrm{R}+\mathrm{L}$ groups showed a good leaf phylloxeration level with about half of the crown infested. All meristematic leaves of the plants' apex were infested, while the older mature leaves developed prior to infestation (during the acclimation period) were noninfested, since phylloxera feeds on newly expanding leaves only [6,17]. Hence, at the peak (56 day) of the treatment, about $50 \%$ of leaves showed signs of infection and an average of 35 mature galls could be counted on the five mostly galled leaves per plant. The results are in accordance with recent studies warning about an increased incidence of leaf-feeding phylloxera on $V$. vinifera scions of traditional cultivars, as well as on hybrids with American parentage (as in our case) and the presence of more aggressive insect strains inducing gall formation $[2,10]$. On the other hand, the belowground insect development in our trial was more limited with about 30-80 nodosities counted per each root system. Furthermore, the insect population could not be observed on the roots of $50 \%$ of plants. The issue of Kober 5BB vulnerability to phylloxera has been controversially discussed in the literature and the rootstock has been recently denoted as resistant $[1,3]$ tolerant $[4,10]$ and even highly susceptible [8]. Our results confirm the tolerance of the rootstock Kober 5BB to the specific phylloxera strain used for inoculations, but we are aware that the environmental conditions [5] and the insect aggressiveness play important roles in the host-plant interaction and can significantly modulate it $[1,6]$ Hence, speculations on what caused the failure of infection on roots of some plants are difficult to test particularly in view of the fact that neighboring $R+L$ plants were successfully root infected.

Via monitoring of vines water status, we found evidence that $D$. vitifoliae may limit the rate of transpiration by depressing stomatal conductance, without apparently impacting photosynthesis. These results suggest that phylloxera (on leaves or whole plant) is potentially able to increase the water use efficiency (WUE, defined as the ratio of A and $\left.\mathrm{E}_{\mathrm{L}},[22]\right)$ of host plants, a fact further supported by the $\Psi_{\text {leaf }}$ measurements highlighting a more conservative water strategy in leaf-infested plants compared to $C$ (i.e., $\Psi_{\text {leaf }}$ by about $0.18 \mathrm{MPa}$ higher). We think that, even if limited, the difference of $0.18 \mathrm{MPa}$ can anyway have some biological importance in plants due to higher turgor pressure and higher cell sap osmotic potential resulted from less negative $\Psi_{\text {leaf }}$, all factors playing important roles in the modulation of stomatal aperture and water/metabolites [23-25]. Hence, we can speculate that the withdrawal of sugars and other nutrients by phylloxera population (see below, Figure 3) might have induced a slight increase of the leaf osmotic potential and, consequently, a higher $\Psi_{\text {leaf }}$. The insect would benefit from this enhanced metabolic equilibrium, since the host vines operate in a "safe range" of the carbon assimilation vs. water loss spectrum. As a consequence, plants maintain good performance reducing the risk of abiotic stress-induced physiological alterations, as for example embolism formation and carbon starvation under water stress [22,26]. A similar trend toward higher WUE was observed in Savi et al. [5] where the effects of root phylloxeration on leaf gas-exchange were addressed on a different scion-rootstock combination. Unfortunately, our results cannot be compared to one other study describing the effects of leaf phylloxeration on vines gas-exchange using a third study species [18], since the latter did not include a control group of noninfested plants to which relate the traits measured in infested leaves. Nevertheless, Nabity et al. [18] did not find clear differences in A between galled and nongalled tissue of the same leaf, even if an increased stomatal density was observed in proximity to the galls, a trait suggested to promote the importation of carbon into the leaf.

At first sight, the treatments $(C, L$ or $R+L)$ did not influence NSC content in leaves, while a marked effect was observed in roots (Tables 1 and 2). Caution is suggested in the interpretation of carbohydrate results, since the variations are sometimes large, especially in some sugars and plant tissues, limiting the statistically significant results. The plant apex generally acts as a nutrition sink $[27,28]$ and is the only site where phylloxera can induce galls. However, although intense pest infestation, significant sugar allocation toward this organ was not observed. Phylloxera reproduction (stage in the insect's life cycle characterized by strength to attract sugars) starts when the leaves are more mature, 
possibly explaining the lack of sugar flow to the apex. A closer look to aboveground organs revealed significant soluble NSC depletion in galled tissue ( $-45 \%)$ compared to nearby noninfested leaf portion, demonstrating high metabolic activity and strong sink strength of the galling habit (Figure 3). Even if the NSC were never directly measured in infested and noninfested leaf so far, the primary results of Nabity et al. [18] support our conclusions. In fact, with stable isotope labeling this latter study highlighted lower total $\mathrm{C}$ content, coupled to higher gene expression related to glycolysis, in galls than in the ungalled tissue. Similarly, Warick and Hildebrandt [29] found 50\% lower total N concentration in galls relative to noninfested leaf, but specific amino acids showed different abundance in the two tissues, with some being more concentrated in the galls (serine, alanine), while others in the leaves (leucine, glutamine). This lower nutrient concentration in the galls wall could play roles in the protection of phylloxera population from other herbivores and necrotrophic fungi.

Compared to the leaves, phylloxera had a stronger effect on carbon partitioning and sugar concentration on the belowground organs. Parallel to a significant reduction $(-65 \%)$ of glucose, fructose and sucrose, $390 \%$ higher starch concentration was measured in infested than in noninfested root tips. Accumulation of starch in root nodosities was reported plenty of times $[11,13,30]$ and represents long-term nutrient storage allocated in permanent organs aimed at supporting the pest fitness. On the other hand, considering that simple sugars are fundamental for phylloxera diet [1], their withdrawal from nodosities likely leads to an increased osmotic potential which promotes nutrient translocation from nearby sugar-rich tissues and/or starch breakdown to simple sugars [13]. Our results suggest that $D$. vitifoliae may stimulate the translocation of sugars from undamaged roots (noninfested root tips and old roots) toward the insect habit leading to starch reserves accumulation in nodosities at the expense of the noninfested plant tissue. On the other hand, more information is needed to elucidate which fraction of this "missing biochemical energy" was actually invested by the plant in the secondary metabolism to promote defense mechanisms against the pest [31-33]. Thus, considering the metabolic reprogramming, as well as the strong sink of both root and leaf insect population, the difference in total biomass observed between control and phylloxerated plants (Figure 2) could be expected. Leaf or root phylloxera infestation similarly caused decreased plant vigor and growth in different grapevine cultivars $[3,5,12,17]$. However, the biomass reduction was more striking in the $\mathrm{L}$ group compared to $\mathrm{R}+\mathrm{L}$, as a likely consequence of root nodosities in the latter group, which represent a permanent long-term storage tissue for the insect that increases the belowground biomass [30].

To the best of our knowledge the effects of both leaf and root galling on vine physiology have not been studied so far. We found evidence that whole plant infestation leads to a stronger impact on some of the studied traits (in particular sugars of leaf galls and roots) compared to leaf infestation only. In particular, sucrose was more depleted $(-22 \%)$ in the galls of $\mathrm{R}+\mathrm{L}$ than in those of the $\mathrm{L}$ group, a difference that was found to be statistically significant. Similarly, lower soluble NSC were measured in the healthy root tips of R + L plants compared to L (153 vs. $261 \mathrm{mg} \mathrm{g}^{-1} ; p<0.05$, Student's t-test), suggesting that whole plant infestation markedly reduces sugar availability for both plant and insect metabolism (Table 1, Figure 4). We do not exclude that whole plant infestation may induce an even worse physiological depression of that highlighted in our trial, potentially impacting yield and grape quality. In fact, the lack of clear differences between $\mathrm{R}+\mathrm{L}$ and $\mathrm{L}$ groups in some of the measured parameters (for example $-23 \%$ and $-10 \%$ of leaf starch and old roots' simple sugars, respectively; $p>0.05$ ) may be due to the limited number of replicates (5-8), relatively high data variability, or to the quite scarce insect proliferation on roots (see above). All these factors might have played an important role in hampering the detection of further significant differences between the two experimental groups.

\section{Conclusions}

We demonstrated that phylloxera significantly affects the metabolism and alters source-sink relationships of the host plant. In particular, the ability of the insect to manipu- 
late its host by increasing the WUE may allow to reduce the negative effects of herbivory and increases the compatibility between the parasite and the vine. Both leaf galls and root nodosities become major sinks of nutrients and draw assimilates away from the rest of the plant. However, even if the root proliferation of the insect was scarce, massive starch accumulation in nodosities, which was not detected in leaf galls, suggests important metabolic differences between the root and leaf organ under biotic attack. Overall, our results reveal, that the combined below- and aboveground biotic pressure induces a stronger physiological depression than the leaf infestation only, pushing the plants closer to the edge of decline. However, note that these results were obtained on a specific scion-rootstock combination using relatively low sample numbers $(<10)$ and they should not be considered universal. Since the data variability was quite high and taking into consideration that rootstock-phylloxera interaction may change under the effects of several factors [1], caution should be taken in generalizing and comparing results.

Supplementary Materials: The following are available online at https://www.mdpi.com/article/ $10.3390 / w 13101429 / s 1$, Figure S1: Microclimatic data recorded in the quarantine cage during the experimental period: average daily temperature (closed circles, left axis) and midday water pressure deficit (grey area, right axis). The two arrows indicate the inoculation and the final sampling day, respectively; Figure S2: Leaf temperature (Tleaf), (a), stomatal conductance to water vapour $\left(\mathrm{g}_{\mathrm{s}}\right)$, $(\mathbf{b})$, sub-stomatal $\mathrm{CO}_{2}(\mathrm{Ci})(\mathbf{c})$ as measured in control (C, closed circles), leaf infested (L, open triangles), and both root and leaf infested $(\mathrm{R}+\mathrm{L}$, grey squares) plants during the treatments application $(\mathrm{n}=$ $5-8)$. n.s. indicates lack of statistically significant differences.

Author Contributions: Conceptualization, T.S. and A.F.; data curation, T.S. and J.C.H.; formal analysis, T.S. and J.C.H.; investigation, T.S.; methodology, T.S., J.C.H. and A.F.; project administration, A.F.; resources, A.F.; software, T.S. and J.C.H.; writing—original draft, T.S.; writing—review and editing, T.S., J.C.H. and A.F. All authors have read and agreed to the published version of the manuscript.

Funding: This research received no external funding.

Institutional Review Board Statement: Not applicable.

Informed Consent Statement: Not applicable.

Data Availability Statement: The data presented in this study is available in the current manuscript, raw data is available on request from the corresponding author.

Acknowledgments: The authors are grateful to Viola Winkler, Eva Maria Raffeiner, Verena Dockner, and Federica De Berardinis for technical assistance during measurements, sampling and NSC analyses. Part of the data described in the paper will contribute to V.W. and E.M.R. bachelor theses. Open access funding provided by University of Natural Resources and Life Sciences Vienna (BOKU).

Conflicts of Interest: The authors declare no conflict of interest.

\section{References}

1. Powell, K.S.; Cooper, P.D.; Forneck, A. The biology, physiology and host-plant interactions of grape phylloxera Daktulosphaira vitifoliae. Adv. Insect Phys. 2013, 45, 159-218. [CrossRef]

2. Forneck, A.; Powell, K.S.; Walker, M.A. Scientific opinion: Improving the definition of grape phylloxera biotypes and standardizing biotype screening protocols. Am. J. Enol. Vitic. 2016, 67, 371-376. [CrossRef]

3. Du, Y.; Wang, Z.; Yang, Y.; Zhao, Q.; Zhai, H.; Wang, Z. Nodosity formation and nutrition consumption in grape cultivars with different phylloxera-resistance and infested by grape phylloxera. Acta Entomol. Sin. 2008, 51, 1050-1054.

4. Korosi, G.A.; Carmody, B.M.; Powell, K.S. Rootstock screening for phylloxera resistance under controlled conditions using selected phylloxera clonal lineages. Acta Hortic. 2011, 904, 33-40. [CrossRef]

5. Savi, T.; García González, A.; Herrera, J.C.; Forneck, A. Gas exchange, biomass and non-structural carbohydrates dynamics in vines under combined drought and biotic stress. BMC Plant Biol. 2019, 19, 1-11. [CrossRef]

6. Granett, J.; Walker, M.A.; Kocsis, L.; Omer, A.D. Biology and management of grape phylloxera. Annu. Rev. Èntomol. 2001, 46, 387-412. [CrossRef]

7. Ruehl, E.; Schmid, J.; Eibach, R.; Töpfer, R. Grapevine breeding programmes in Germany. In Grapevine Breeding Programs for the Wine Industry; Woodhead Publishing: Cambridge, UK, 2015; Volume 268, pp. 77-101. [CrossRef]

8. Fahrentrapp, J.; Müller, L.; Schumacher, P. Is there need for leaf-galling grape phylloxera control? Presence and distribution of Dactulosphaira vitifoliae in Swiss vineyards. Int. J. Pest Manag. 2015, 61, 1-6. [CrossRef] 
9. Mori, N.; Marchesini, E.; Duso, C.; Forneck, A. Nuove infestazioni di fillossera su vite europea: Tra cambiamenti climatici e nuovi biotipi. Inf. Agrar. 2018, 3, 47-52.

10. Forneck, A.; Mammerler, R.; Tello, J.; Breuer, M.; Müller, J.; Fahrentrapp, J. First European leaf-feeding grape phylloxera (Daktulosphaira vitifoliae Fitch) survey in Swiss and German commercial vineyards. Eur. J. Plant Pathol. 2019, 154, 1029-1039. [CrossRef]

11. Kellow, A.V.; Sedgley, M.; Van Heeswijck, R. Interaction Between Vitis vinifera and grape phylloxera: Changes in root tissue during nodosity formation. Ann. Bot. 2004, 93, 581-590. [CrossRef] [PubMed]

12. Du, Y.; Wang, F.; Ji, X.; Jiang, E.; Zhai, H. Phylloxera infestation and the uptake and distribution of ${ }^{13} \mathrm{C}$ and ${ }^{15} \mathrm{~N}$ tracers in grape vines. Vitis 2014, 53, 227-231.

13. Griesser, M.; Lawo, N.C.; Crespo Martinez, S.; Schoedl-Hummel, K.; Wieczorek, K.; Gorecka, M.; Liebner, F.; Zweckmair, T.; Pavese, N.S.; Kreil, D.; et al. Phylloxera (Daktulosphaira vitifoliae Fitch) alters the carbohydrate metabolism in root galls to allowing the compatible interaction with grapevine (Vitis ssp.) roots. Plant Sci. 2015, 234, 38-49. [CrossRef]

14. Cadle-Davidson, L. Variation within and between Vitis spp. for foliar Resistance to the downy mildew pathogen Plasmopara viticola. Plant Dis. 2008, 92, 1577-1584. [CrossRef] [PubMed]

15. Cadle-Davidson, L.; Chicoine, D.R.; Consolie, N.H. Variation within and among Vitis spp. for foliar resistance to the powdery mildew pathogen Erysiphe necator. Plant Dis. 2011, 95, 202-211. [CrossRef]

16. Vezzulli, S.; Vecchione, A.; Stefanini, M.; Zulini, L. Downy mildew resistance evaluation in 28 grapevine hybrids promising for breeding programs in Trentino region (Italy). Eur. J. Plant Pathol. 2017, 150, 485-495. [CrossRef]

17. Granett, J.; Kocsis, L. Populations of grape phylloxera gallicoles on rootstock foliage in Hungary. Vitis 2000, 39, 37-41. [CrossRef]

18. Nabity, P.D.; Haus, M.J.; Berenbaum, M.R.; DeLucia, E.H. Leaf-galling phylloxera on grapes reprograms host metabolism and morphology. Proc. Natl. Acad. Sci. 2013, 110, 16663-16668. [CrossRef]

19. Savi, T.; Petruzzellis, F.; Martellos, S.; Stenni, B.; Dal Borgo, A.; Zini, L.; Lisjak, K.; Nardini, A. Vineyard water relations in a karstic area: Deep roots and irrigation management. Agric. Ecosyst. Environ. 2018, 263, 53-59. [CrossRef]

20. Smith, A.M.; Zeeman, S.C. Quantification of starch in plant tissues. Nat. Protoc. 2006, 1, 1342-1345. [CrossRef]

21. Landhäusser, S.M.; Chow, P.S.; Dickman, L.; E Furze, M.; Kuhlman, I.; Schmid, S.; Wiesenbauer, J.; Wild, B.; Gleixner, G.; Hartmann, H.; et al. Standardized protocols and procedures can precisely and accurately quantify non-structural carbohydrates. Tree Physiol. 2018, 38, 1764-1778. [CrossRef] [PubMed]

22. Sinclair, T.R.; Tanner, C.B.; Bennett, J.M. Water-use efficiency in crop production. Bioscience 1984, 34, 36-40. [CrossRef]

23. Brodribb, T.J.; Holbrook, N.M.; Edwards, E.J.; Gutiérrez, M.V. Relations between stomatal closure, leaf turgor and xylem vulnerability in eight tropical dry forest trees. Plant Cell Environ. 2003, 26, 443-450. [CrossRef]

24. Sala, A.; Piper, F.; Hoch, G. Physiological mechanisms of drought-induced tree mortality are far from being resolved. New Phytol. 2010, 186, 274-281. [CrossRef] [PubMed]

25. Gambetta, G.A.; Herrera, J.C.; Dayer, S.; Feng, Q.; Hochberg, U.; Castellarin, S.D. The physiology of drought stress in grapevine: Towards an integrative definition of drought tolerance. J. Exp. Bot. 2020, 71, 4658-4676. [CrossRef]

26. Savi, T.; Casolo, V.; Luglio, J.; Bertuzzi, S.; Trifilo', P.; Lo Gullo, M.A.; Nardini, A. Species-specific reversal of stem xylem embolism after a prolonged drought correlates to endpoint concentration of soluble sugars. Plant Physiol. Biochem. 2016, 106, 198-207. [CrossRef] [PubMed]

27. Dai, Z.W.; Wang, L.J.; Zhao, J.Y.; Fan, P.G.; Li, S.H. Effect and after-effect of water stress on the distribution of newly-fixed ${ }^{14}$ C-photoassimilate in micropropagated apple plants. Environ. Exp. Bot. 2007, 60, 484-494. [CrossRef]

28. Frioni, T.; Acimovic, D.; Tombesi, S.; Sivilotti, P.; Palliotti, A.; Poni, S.; Sabbatini, P. Changes in within-shoot carbon partitioning in pinot noir grapevines subjected to early basal leaf removal. Front. Plant Sci. 2018, 9, 1122. [CrossRef]

29. Warick, R.P.; Hildebrandt, A.C. Free amino acid contents of stem and phylloxera gall tissue cultures of grape. Plant Physiol. 1966, 41, 573-578. [CrossRef]

30. Eitle, M.; Cargnoni, M.; Acar, A.; Crespo Martinez, S.; Failla, O.; Kaul, H.-P.; Griesser, M.; Forneck, A. Phylloxeration effects on the sink activity and assimilation rate in phylloxera (Daktulosphaira vitifoliae Fitch) infested grapevines (Vitis spp.). Acta Hortic. 2017, 1188, 291-298. [CrossRef]

31. Eitle, M.W.; Griesser, M.; Vankova, R.; Dobrev, P.; Aberer, S.; Forneck, A. Grape phylloxera (D. vitifoliae) manipulates SA/JA concentrations and signalling pathways in root galls of Vitis spp. Plant Physiol. Biochem. 2019, 144, 85-91. [CrossRef] [PubMed]

32. Eitle, M.W.; Loacker, J.; Meng-Reiterer, J.; Schuhmacher, R.; Griesser, M.; Forneck, A. Polyphenolic profiling of roots (Vitis spp.) under grape phylloxera (D. vitifoliae Fitch) attack. Plant Physiol. Biochem. 2019, 135, 174-181. [CrossRef] [PubMed]

33. Nalam, V.; Louis, J.; Shah, J. Plant defense against aphids, the pest extraordinaire. Plant Sci. 2019, 279, 96-107. [CrossRef] [PubMed] 